821: 787.61

https://doi.org/10.18485/kud_kp.2018.ch7

\author{
проф. др Урош Дојчиновић \\ Факултет савремених уметности, Београд
}

\title{
УВОД У АНАЛИТИЧКИ ПРИСТУП УМЕТНИЧКОЈ КЊИЖЕВНОСТИ С СТАНОВИШТА МУЗИКЕ
}

\section{Сажетак}

Интердисциплинарно проучавање књижевности и музике подразумева свеобухватни приступ двема изузетно комплементарним хуманистичким областима. Њихово стално преплитање, у коме музика и сви њени аспекти констатано задиру у филологију, рађају један нови и комплексан однос, који се може дефинисати као музичка феноменологија у књижевности. Овај рад је посвећен феноменолошком истраживању свега музичког присутног у књижевности, кроз конкретне примере. Трагајући за књижевном грађом, која упућује на различите музичке аспекте, пре свега оне повезане са одређеним музичким инструментима на српском простору, аутор овог текста је својим практичним истраживањем дошао до низа нових чињеница, врло значајних за ову тему. Анализа обимне уметничке књижевне продукције, најприје је потврдила занемарљив број домаћих дела у којима нема никаквих трагова музичке проблематике, док је већина показала читав спектар различитих веза са музичком уметношћу у најширем смислу.

Кључне речи: књижевност, музика, аналитички приступ, музичка феноменологија у књижевности

Сам наслов упућује да је реч о научном разматрању које се дотиче две комплементарне уметности: књижевности и музике. Другим речима, незаобилазно прибе- 
гавање интердисциплинарном проучавању, које за реализацију сваког таквог научног пројекта подразумева мултидисциплинаран приступ, јасно отвара једно ново подручје рада и омогућава сасвим нове углове сагледавања и тумачења свеколиких веза прожимања две изузетно компатибилне хуманистичке области. Њихово стално преплитање, у коме музика и сви њени аспекти у најширем смислу констатано задиру у филологију, рађају један нови и комплексан однос, који се може једноставно дефинисати као музичка феноменолоїија у кюижевносӣи.

Као термин феноменолоїију чине две грчке речи: phainomenon (појава) и logos (ум, разуманговор, наука), те би најближи превод ове сложенице означавао науку која проучава појаве, тј. науку о појавама, као и свим осталим облицима дешавања, збивања, силама и другим феноменима, које је могуће проучавати у односу на њихов развојни пут и међусобне везе. Прве помене феноменолоїије налазимо још у 18. веку, када је превасходно представљала науку која се бавила различитим феноменима. ${ }^{1}$ Захваљујући немачком филозофу Едмунду Хусерлу (1859-1938), али и његовим следбеницима, током 20. века феноменологија се развила у посебан правац у филозофији. Филозофска становишта су знатно проширила њено значење, омогућавајући јој далеко комплексније и свеобухватније сагледавање и третирање одређених проблема: нашој свести је пружена могућност опажања и откривања нечега, неке суштине, која нам се појављује и приказује унутар наших властитих свеукупних психичких доживљаја, фигуришући иза саме појаве, као њен извор, смисао, суштина (срж или бит) итд. Интересантно је поменути да су се доста рано међу немачким филозофима формирала супротна мишљења; такви дијаметрално различити погледи формулисани су у гледиштима Имануела

И данас у колоквијалној употреби термин феноменолоїија упућује пре свега на реч феномен чије основно значење подразумева неку одређену йојаву. 
Канта (1724-1804), који је негирао способност теоријског спознавања суштина или бити идеја, искључивши их из домашаја људског спознавања и знања, тј. подручја теоријског ума и остављајући их вољи практичног ума. Суштински, Кантово становиште је било да човек није у стању да теоретски спозна било какву суштину идеја, већ само оне појаве које може да региструје својим чулима. ${ }^{2}$ Супротно, феноменологија је код Георга Вилхелма Фридриха Хегела (1770-1831) представљала допирање до суштине апсолутног знања о себи самом, оног битног сазнања када дух постаје свестан свог бића. Хегелова позиција је наиме истицала сваку појаву као појаву суштине ствари, тј. приказ „искуства свести“ у њеном дијалектичком самокретању. По њему је феноменологија приказ посредоване појаве саме бити апсолутног духа, тј. приказ свести у покрету, од момента непосредне супротности свести и предмета, до апсолутног знања.

Након Хегела уследио је период позитивистичког промишљања, који је инсистирао само на оним позитивним научним чињеницама, до којих се искључиво долазило истраживањима базираним на искуственом и чињеничном, елиминишући као тотално неупотребљив и бескористан било какав метафизички приступ. Феноменологија је тада изједначавана са општим научним ставовима, чија тежња је била само верно, прецизно и тачно описивање чињеница и појава из тзв. емпиријског света, без упуштања у њихову суштину и смисао. Међутим, и поред таквих заговарања, блиских чак и гледишту Хусерла, и код њега је уследио покушај повратка и начина досезања до „самих ствари“, у односу на њихову суштину и смисао, тј. враћање самим феноменима. Феноменологија ће постати филозофски метод и наука која ће омогућити јединствено обухватање и разумевање свих подручја стварности и

2 Према Имануелу Канту доношење закључака о суштини ствари на основу појаве доводи до погрешног закључивања или паралогизма, тј. ненамерно начињене погрешне конклузије. 
унутар других научних дисциплина. Она је постала јединствена и универзална научна основа, која премоштава и превазилази релативизам других, многобројних, супротстављених филозофских и научних теорија и система. Откривајући под којим су условима сазнања заиста могућа, шта је у процесу мишљења сам предмет мишљења, феноменологија дефинише науку као уређену целину безрезервно протумачених и објашњених сазнања. Хусерл је одредио и појам есенција као основа за опис „самих ствари“; а постигнуте не-емпирјским истраживањем, оне по

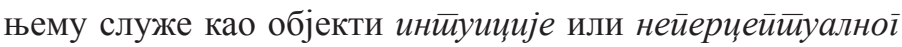
виђена. ${ }^{3}$ Феноменологија дакле елаборира појаве које се изворно појављају нашој свести, а не ствари или предмете који постоје изван ње. Сваком предмету мишљења треба дозволити да у нашој свести буде приказан у свом суштинском облику, другачије - за успешно истраживање потребно је успоставити метод сазнања који предметима нашег промишљања неће додавати ничег новог, изван њиховог суштинског. Али исто тако, према феноменолошком виђењу, егзистенција света око нас не би имала смисла када би била независна од наше свети.

Мала дигресија у односу на општи приступ феноменологији, а у циљу илустрације деловања наше свети при перцепцији, у овом случају, одређених илустрованих примера, можда понајбоље може да истакне феноменолошки моменат конкретних ситуација. Погледајмо следеће две прозаичне илустрације под називом Серенада, које се свакако нижег естетског квалитета, али с тенденциозним емотивним набојем, рађене очигледно с претензијом допадања најширем кругу корисника:

3 По Хусерлу такве есенције су ништа друго до феномени, па њихово истраживање чини управо феноменолоіију. 

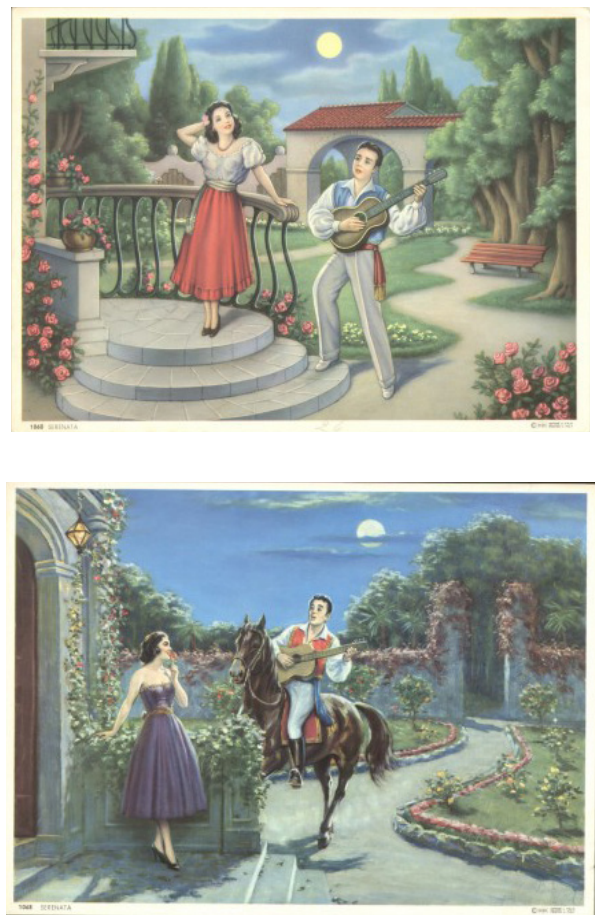

Јасно је да оба призора приказују идиличне тренутке, удварања и исказивања нежности музицирањем на гитари, иако то није експлицитно наведено. Наравно, приступ оваквом схватању и тумачењу у многоме зависи не од приказаног рада, колико већ и креативног односа реципијента, његове социолошке, културолошке и др. позадине. Питање је да ли би за нас исто значење имале ситуације на сликама, уколико у нашој свести нису успостављени параметри већ усађених, изграђених вредности за појмове као што су: љубав, романтика, удварање, умилни звук одређеног инструмента (у овом случају популарне їитаре) и сл. Супротно, присетимо се различитих милитаристичких тема, каква је засигурно следећа фотографија српске војске у маршу, који се одвија уз звуке друга два музичка инструмента, итрубе и gобоша: 


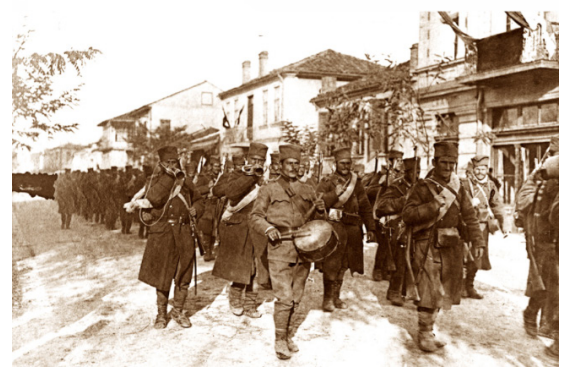

Превасходно захваљујући својим тонским и техничким особинама, изражајне могућности одређеног броја музичких инструмента су им већ на глобалном нивоу поделиле значајне улоге, усталивши их као врсна пратећа и помоћна средства људске комуникације, с посебним експресивним одликама. Дакле, с тих позиција незамисливо је нпр. очекивати војнички добош у рукама мушке особе која се удвара, као и пријатне и тихе тонове лаута или гитара у војничком строју.

Апстракција саме музике као уметности, уз ослонац на лично искуство и живу музичку праксу у реалном окружењу, обогаћени Паћијевим погледима на дијалектику конкретног и абстрактног, ${ }^{4}$ већ су довољно оправдање таутолошког односа према музичким информацијама у књижевности, и онога што је стварност - „чињеница по себи“. Зађемо ли нешто дубље у феноменологију овог италијанског аутора, за кога је истинитост знања осмишљена, строго заснована, односно интенционална, али се ни духовне ни природне науке не могу и не смеју свести само на објективност и фактичност, онтолошке паралеле до којих долазимо у оквирима ове материје, учиниће нам се само веродостојнијим. Корелативни однос на којем се заснива комплетно гледиште указаног феномена, може се посматрати из оба угла; полазишта се могу кретати од

4 Funzione delle scienze e significato dell' uomo / Enzo Paci. - Milano: Il Saggiatore ; 2. ed., 1964. - str. 440 - 464. 
конкретног примера у делу - ка стварном у животу, али и од познавања реалних ситуација у окружењу, ка њиховим литерарним пројекцијама.

Послужићемо се стиховима прве строфе песме Деg и унук, Јована Јовановића Змаја (1833-1904), који наглашено сведоче у прилог културно-историјског утицаја простора на којем су настали:

Уз'о деда свог унука

Метн'о га на крило,

па уз гусле певао му

Шта је негда било.

Аналогни случај била би песма Гийара, шпанског песника Федерике Гарсије Лорке, која почиње стихом:

Почиње тужаљка гитаре.

Третирани с мултидисциплинарног становишта изабрани инструменти искоришћени у обе песме, недвосмислено указује на њихово стварно постојање и примену у музичкој пракси оба поднебља. Колика је логичност компатибилности ових веза, уколико располажемо фактима: место, време и културолошко-музичка позадина, посебно би се истакла и примером апсурдног обрта, какав би за Лорку био стих: „Почиње тужаљка гусала“, или за Змаја: Србин деда, који свом унуку о националној историји уз гитару пева. Другим речима, када би посматрали комплетан опус наше епске поезије, уз уважавање чињеница које доноси историја књижевности и музике, општа национална историја и сл, све песме с поменом гусала, могу постати потенцијални материјал за разматрање најшире проблематике тог гудачког инструмента. Стихови који упућују на његову употребу, или посредно указују на било какав (чак и емотиван) однос, аутора (извођача) и слушалаца (заједнице) према гуслама, извођењу и самој музици, оправдано сврставају овакве песничке творевине у релевантну библиографску грађу с становишта музичке феноменологије. 
Посебно у ситуацијама недостатка других извора информација, као што су код нас релевантни споменици српске средњовековне музичке културе, епска поезија пружа идеалне податке о тадашњим музичким инструментима.

Потребно је указати на још неке аспекте феноменолошких теорија и приступа, који су били полазишта нашег промишљања, јер иницирају нови угао посматрања. Један други немачки филозоф Мартин Хајдегер (1889-1976) је феноменологију изједначавао са онтологијом - „науком о бићу бивствујућег", сматрајући их истозначним дисциплинама, које по предмету и начину обраде карактеришу филозофију. ${ }^{5}$ И он, као и већина његових савременика, али и потоњих мислилаца, свој феноменологију - вид филозофског размишљања, инспирисао је аутентичним Хусерловим учењем. Антиципирајући само она полазишта, чија је логичност и транспарентност допуштала примену у спектру нашег научног разматрања, као потврду правилног избора, у феноменолошком истраживању свега музичког присутног у књижевном ткиву, може се постићи њихова јасна, конкретна и недвосмислена транскрибција, у ,jезик-подручја“ оваквог рада. Већ у првим промишљањима сличних идеја феноменологије, и Хусерл се јасно поставио у односу на просуђивања о свету и односима који владају међу стварима и до којих долазимо непосредним искуством. На основу таквог искуства, из ,директно сазнатог", преносом генерализоване, уопштене спознаје на појединачне случајеве, или аналитичким дедуковањем нових уопштености из уопштених спознаја, закључујемо оно што је непознато (несазнато). Логички след спознаја, њихово међусобно слагање и потврђивање, управо је било и код нас агенс изналажењу корелата код проблематике музичких инструмената. Прегледаћемо следећи пример:

Ако се корени повезаности песништва и инструмента

\footnotetext{
5 “Филозофија је универзална феноменолошка онтологија, полазећи од херменаутике људске егзистенције” : Sein und Zeit / Martin Heidegger. - Tubingen: M. Niemeyer Verlag, 1963. - str. 38.
} 
лире протежу до античке Грчке, ${ }^{6}$ а њене уметничке тековине, вековима касније обухватиле образовање широм Европе, именовање календара „Београдска лира“"7 (Београд, 1833-1835), није ни случајно ни нелогично. Григорије Возаревић је тенденциозним коришћењем назива овог инструмента, свесно сигнализирао читав низ одређености. Најпре, упутио на лично или опште познавање античког песништва и култа лире, покренуо питање естетских компоненти свог штампаног медија, донекле артикулисао врсту књижевне грађе коју је презентирао и дотакао се круга

6 Различита истраживања су потврдила да су древни Хелени, иначе високо развијене културе, гајили посебан однос управо према поезији и музици. Имали су природни дар за обе уметнсоти, па је појам анер мусикос (aner mousikos) код њих означавао свестрано образованог човека. Присетимо се и Платоновог уверења да ће држава бити онаква - каква је у њој музика, и да су песма и певање пратили хеленски народ практично од рођења до смрти. Њиховим најстаријим му-

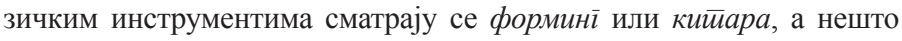
кансије и лира. Магична моћ звукова тих инструмената приписивана је митским певачима као што су Аполон, затим његов син Орфеј, Амфион, Марсија и многи други. Даље, најстарији трагови народног песништва које срећемо код Хомера показују да је стара хеленска народна поезија била хијератског, набожног карактера, упућена боговима на Олимпу (Зевсу, Аполону и др.). Главна одлика те световне поезије и певања, судећи и према Илијади и Одисеји, била је глорификација побожног карактера, која је повезивала народно с култним песништвом. На тај начин хеленске музе су трајно направиле прво свој продор у народу, а потом и у уметничку књижевност. Још је у Платоново време започето проучавање апелатива античких муза. Он се међу првима почео бавити питањима разумевања једног језика, разматрајући две могућности: поимање природним путем, у складу са етимологијом самих речи или поштујући усвојене конвенције. Поменућемо и да је прва и најстарија врста лирско-епске субјективе римоване поезије код старих Грка названа елеїија.

7 Слично је и са Српском лиром, која се појавила у Дубровнику, из Српске штампарије А. Писарића, 1904. године, и садржи избор различитих песама, међу којима и двие љубавне, карактеристичних наслова: (41) Тамбурица сийним йласом ... и ( 52) Уgарало у йамбуру Баче. 
реципијената. ${ }^{8}$ Постоји мноштво сличних аналогија. ${ }^{9}$ Такве и сличне рефлексије спознаја су психички доживљаји, по Хусерлу „психолошки фактуми“, чији се облици и врсте генетичких веза могу посебно истраживати и описивати. Својствени су само човеку и везани за људске интелектуалне форме.

Трагајући за књижевном грађом, који упућује на различите музичке аспекте, пре свега оне повезане са одређеним музичким инструментима на српском простору, аутор овог текста је својим практичним истраживањем дошао

8 Посебну симболику и функционалност везану за музичке инструменте налазимо у античким легендама и митовима. Дотакнимо се само неких одлика лире као коришћеног медија, које могу да појасне наводе: сам изглед инструмента, чак и у најопштијој схематизованој верзији (два елегантно извијена крака, која подсећају на пера пауновог репа, повезаних неколицином правих, вертикално постављених црта - „струна“, попречно укрштених при врху кракова са једним кратким, хоризонталним), као и примене инструмента (музицирање са пратећом улогом, најчешће довођено у везу са песничким интерпретацијама), исти доводи у контекст са лепим књижевностима, имагинацијама какве нуди поезија. Мало је вероватно да би гласилима у области природних наука (нпр. хемије, биологије и сл.), термин лира могао да послужи у наслову, са метафоричком функцијом. Истовремено ове одређености указују и на круг потенцијалних интересената за публикацију с таквом садржином. Он свакако може бити јако широк, али пре свега обухвата љубитеље уметничке књижевности и оне чије је интересовање у домену друштвених наука. Даље, наслов посредно указује и на сам садржај публикације, па би било врло неосновано очекивати да исти доноси материјал какав су нпр. логаритамске таблице, математичке једначине и сл. Дакле, вишезначност употребљеног термина представља врсан феномен, погодан за различите анализе.

9 Поменимо да су збирке популарних и радо певаних грађанских песама - иесмарище, које су се појављивале током 18. и почетком 19. века, често називале «лире»; Детаљније у: Српска грађанска поезија XVIII i s početka XIX столећa / [приредио] Боривоје Маринковић. Београд : Просвета, 1966. - стр. 9-95; Такође, један број песника је и даље користио инструмент лиру, као мото својих лирских збирки и књига песама: поменућемо Васу J. Исаиловића (1878-1956) и његову збирку песама Први звуц̧и лире, објављен у Новом Саду 1898. године. 
до низа нових момената, врло значајних за ову тему. Разматрање односа између места и положаја који музички инструменти имају у стварном животу, и оних које открива уметничка литература, изнедрило је занимљиве законитости и својеврсне феномене. Анализа обимне уметничке књижевне продукције, најпре је потврдила занемарљив број домаћих дела, у којима нема никаквих трагова музичке проблематике, док је већина показала читав спектар различитих веза са музичком уметношћу у најширем смислу. Наравно, треба истаћи да је читање литературе, с циљем проналажења релевантних библиографских јединица, откривало мноштво и по облику и садржају, различитих радова, најчешће већег обима, који се врло ограничено дотичу музичких области. Тако, прозно књижевно дело од више стотина страна понекад садржи само једну, две или тек неколико реченица, мериторних за разматрање, а када је реч о одређеној песми, количина круцијалних информација неретко је сведена и на само неколико речи. Уколико би из овим, из контекста издвојеним деловима, пришло само са становишта филологије или лингвистике, без ширег посматрања које омогућавају етнолошке, социолошке, психолошке, или друге анализе, састављена библиографија учинила би се с абсурдним пописом јединица, које немају никакве међусобне повезаности.

Управо филозофско сагледавање музичке проблематике, у нашем случају музичких инструмената и онога што је везано за њих коришћено као литерарни материјал, а у контексту различитих књижевних ситуација, доводи до нових чињеница. Ако би исту третирали као посебна лингвистичка средстава, постаје врло прагматична компонента књижевне комуникације. Даље тумачење њихове имплицитне и трансценденте моћи, омогућава проналажење нових димензија, које управо ти музички инструменти имају на свеукупној културној сцени. ${ }^{10}$

\footnotetext{
10 У овом случају српској, но исти аналитички модел истраживања применљив је и на глобалном нивоу.
} 
Иако је већ наглашена комплементарност музике и књижевности, треба подвући да музика доминира и питањем фингирања стручних судова у подручјима других хуманистичких дисциплина. Симболика и компаративност, која се може постићи задирањем у њену стручну проблематику и применом исте, чак и код наизглед удаљених научних области, изузетна je. ${ }^{11}$ Наведено управо илуструје рад америчких антрополога, Едварда Хола (Edward Hall) и Џорџа Tрејгера (George Trager), који разрађују метод анализирања културе, као први-основни корак бележећи: „Утврђивање творних чинилаца културе које смо касније назвали изолатима културе, а који одговарају нотама у музици“. ${ }^{12}$ На аналогију ,речима и реченицама језика“ и ,пасажима у музичком извођењу“ указује и британски антрополог Едмунд Лич, ${ }^{13}$ док се Леви Строс (Levi-Strauss) служи веома сложеним музичким метафорама како би упутио на структурну сличност између музике и мита. ${ }^{14}$

Наравно да литерарна пракса познаје и обрнуте случајеве, нпр. када су појмови из музичке области, у циљу

11 Теоријски приступ интеракцији језика и друштвеног живота, као и односом говорне и музичке комуникације, посебно се бавио Дел Хајмз (Dell Hymes). Детаљније у: Етнографија комуникације / Дел Хајмз. - Београд: БИГЗ, 1980. - 382 стр.

12 Описи природе, природних појава, географских предела и сл, поређењем са музичким појмовима, рано срећу у српској књижевној пракси; Доситеј Обрадовић у свом Живойу и ирикљученију описујући савршенство изгледа околине Срема у І-части Почейка мојеїа йуйовағь $а$ наводи: «тако слаткослишну музику да доведе човека у савршено заборављање себе и у истопљеније ума». У ІІ-части говорећи о лепом времену Доситеј пише: «Сила Божија музиканата и комедијаната мужеескога рода и племена! Преко дана лепо време; такове музике и појања-ван да опет ту «, а затим поново музичка асоцијација када помиње лоше вриеме, буру и олују: «Те музике опет и тога завијања ко није чуо, нек не жели чути «. Видети у: Изабрана дела / Доситеј Обрадовић. - Београд : Политика: Народна књига, 2005. - стр. 97-178 13 Неми језик / Едвард Хол. - Београд : БИГЗ, 1976. - стр. 35. 14 Култура и коминикација / Едмунд Лич. - Београд: Просвета, 1983. - стр. 14. Исти аутор се у својим анрополошким размишљањима, у наведеном делу, често обраћа различитим музичким аналогијама. 
изражајнијег одређивања, упоређивани са књижевним. ${ }^{15}$ Шпански писац Еугенио д’Орс једном приликом записује: «Песма клавира је говор, песма виолончела је елегија, песма гитаре је ... песма «. ${ }^{16}$

Посебно надахнуће, као и личну упућеност у обе друштвене области, књижевници неретко откривају управо у делима у којима инспиративно говоре о уметности - музици и музичарима. Примера је много, како у домаћој, тако и у светској књижевности. Поменућемо Фридриха Ничеа (Friedrich Nietzsche) који у Samtlich Werke (Сви раде) говори о Вагнеру; Роману Ролану (Romain Rolland) који пише о животу Бетовена, или Нину Берберову која за тему има биографију Чајковског. Представљајући се правим еквилибристима, истанчаног укуса и слуха, они врло вешто и зналачки прожимају књижевна ткива најшире тематике, са проблематиком музичке палете. ${ }^{17}$

Књижевна критика пружа изузетно експлицитне примере оваквог музичког кодирања, а филозофске медитације у том правцу досежу и много даље: за Јована Скерлића „Змај је за пола века био Еолова харфа целог српскога народа, певао је што је осећало неколико наших нараштаја“"18. Војислав Илић је ,запевао сасвим другим звуцима““ и по-

15 У својој студији о Јозефу Суку, Војислав Вучковић пише: «А та музика је све једна епска исповест, аутобиографија једне велике романтичарске личности». Видти у: Студије, есеји, критике (19421967) / Војислав Вучковић. - Београд : Нолит, 1968. - стр. 307.

16 Andres Segovia / George Clinton. - London : Musical New Services, 1978. - стр. 97

17 Описујући живот музичара Жана Кристофа, у свом истом роману, француски аутор Р. Ролан постиже врхунац оваквог умећа: „То су били једва додирнути акорди, боје које су звониле као звона, хармоније које су зујале као пчеле, мелодије насмејане као заљубљене усне. То су била привиђења предела, лица, страсти, душа, карактера, књижевних замисли, метафизичких замисли. То су били велики планови, огромни и немогући, тетралогије, декалогије, које су хтеле да све насликају музиком и обухватале читаве светове“.

18 Огледи и критике / Јован Скерлић. - Београд : ИП ”Рад”, 1975. - стр. 101-102 
казао у својој поезији „сву гипкост и музикалност ${ }^{66}{ }^{19}$ Слободан Јовановић сматра да је реченица Љубомира Недића „логички добро склопљена, али не и музички, изгледала је тешка, и тек у полемици добила живљег покрета““. ${ }^{20}$

Филозофу Љубомиру Петровићу музика је била бољи јемац тврђења него и једна друга уметност. Имајући за мото Тенову изјаву да човек само у музици ствара, истиче да је „музика стихова јединствена“, речи су по њему „знаци и у исти мах звуци; реченице и стихови, мисли и уједно мелодије“. ${ }^{21}$ Читајући стихове Ђуре Јакшића он у њима слуша „песму коју грло пева, а чије речи не чује као речи са одређеним смислом него као тонове“. Сву пажњу обраћа на „боју гласа, на осећање које грло одаје, на ритам мелодије“. ${ }^{22}$ По Петровићу је „као Бранко, и Змај врло често налазио својим осећањима музикалних израза. Ма колико да се поводио за туђим утицајима и био је 'гибак дух' - и то у овом, музичком смислу - он је, кад год је хтео да ослушне самог себе, налазио за изливе своје питоме и нежне душе музику нежну и присну, нешто сетну и дискретну“. ${ }^{23}$ А осећајност естетике српског језика у поезији Лазе Костића, Петровић доживљава као музика, са некаквог инструмента, на којем се ,може одсвирати једна болна песма, дубоко осећање стрепње које би можда и сама музика изневерила“. ${ }^{24}$

Међутим, не треба превидети да и код прецизно образложених, природно спознатих претпоставки којима оперишемо, увек постоји присуство спознајно-критичких сумњи.

19 Исто. - стр. 208

20 Из наше историје и књижевности / Слободан Јовановић. - Београд : Српска књижевна задруга, 1931. - стр. 162.

21 Могућности: Претпоставке о пореклу уметности (писмо), митридат, естетика српског језика, граматичка питања, поводом Флоберове преписке (писмо) / Љубомир Петровић. - Београд : «Уједињење», 1928. - стр. 25.

22 Исто. - стр. 27.

23 Исто. - стр. 28.

24 Исто. - стр. 32. 
Охрабрење ипак пружа Хусерлова тврдња да уопште сваки доживљај по свом протицању, као апсолутна датост - нешто бивствујуће, може постати предмет чистог посматрања и схватања. Даље, спознаја се не може разрешити на основу унапред трансцендентног знања, унапред датих ставова о нечему. Не може се дедуковати, логично изводити из знаних, а не уочених егзистенција. Сам Хусерл примећује, да би неко себи представио музички дело и схватио могућности и улогу тонова у стварању, мора бити способан да ту музику чује. Уколико је глув, знање о егзистенцији тонова, познавање хармоније и слично, неће му помоћи у дедуковању дивне уметности звука. Становишта смо да и књижевници, који су се често обраћали музици и музичкој проблематици, никако нису могли бити по страни када је ова уметност у питању. Свако ко је директно, детаљно и стручно, залазио се у проблематику музичког ткива, описивао и износио судове о извођењу (музичкој креацији), или разматрао технику свирања, уколико није лично свирањем стварао музику, морао ју је имати и слушати у свом окружењу. Само оне књижевне асоцијације и имагинације које су имплициране стварним, могу да резултирају у оправдано релевантне написе и литерарне творевине. Такве онда садрже артикулисане елементе музичке материје, почевши од терминологије, који омогућавају фундирање различитих феноменолошких спознаја, а самодостост ових суштина могуће је интуитивно и научно разрађивати.

Овакво гледиште је од изузетног значаја за аналитичка разматрања књижевног опуса насталог у одређеним периодима, какав је нпр. 19. век у Србији. Код писаца тог раздобља, почевши од песника романтичара Бранка Радичевића (1824-1853), народно стваралаштво је пронашло посебног одјека. Захваљујући јасноћи перцепција, искреним и живим асоцијацијама и освртима на доживљено (на оно што јесте или било присутно у њиховом окружењу - у народу), ова дела откривају високу документарну вредност. Такве регистроване и у целину правилно уклопље- 
не парцијалне спознаје, разоткривене у књижевној грађи, омогућавају пре свега реконструкцију низа комплексних мозаика различитих музичких инструмената. Док је полетни Бранко умео да на звуке гајдаша поскочи и у колу се ухвати, дотле су поједини књижевници знали лично да на инструментима засвирају, ${ }^{25}$ а било је и оних који су са доста ерудиције приступали музичким темама. Испод њихових пера појављивали би се занимљиви и често врло стручни текстови и чланци. Један, који је предњачио својим занимањем за музику и интелектуалном дубином посматрања, био је поменути Јован Јовановић Змај. ${ }^{26}$

Квантум музичке терминологије, структура стихова и реченица, из којих зрачи музика и музички обојено размишљање, просуђивање и најзад закључивање, неретко веома искуствено утемељено, формирали су богату књижевну грађу у којој искре музички феномени. Учестало ослањање и потпомагање музичким фондом, покреће и семантичка питања и може постати предмет посебног проучавања лексикологије. Надаље, сама генеза интересантне и често сложене контактологије комплементарних уметности може се интердисциплинарно разматрати у

25 Издвојићемо: Милована Глишића (1847-1908) који, иако је растао уз чобанско музицирање на фрулици, по сопственом исказу је „лепо знао ударати у гитар“; Анка Обреновић (1821-1868), прва жена књижевница у срцу Шумадије, Шапцу, свирала је клавир; Јован Грчић Миленко (1846-1875), песник омладинског периода, који је са дирљивом једноставношћу говорио о младалачком сеоском животу, поседовао сопствену тамбурицу; Милица Стојадиновић Српкиња (1830-1878) често је утеху покушала пронаћи у тоновима своје гитаре: „Најпосле са звуком гитара проба друго’ расположење потражити, но залуду. Жице су издавале тихотужне мелодије, у којима Србин своју судбу приповеда““ бележи Милица у свом Дневнику; песник Милана Ракића (1876-1938), одлично је владао и пером и клавиром; песник, есејиста и романсијер, Раде Драинац (1899-1943) је свирао виолину итд.

26 Више видети у: Критике, чланци и посебне публикације у српској музичкој прошлости (1825-1918) / Роксанда Пејовић. - Београд : Факултет музичке уметности, 1994. - стр. 58-60. 
оквиру ширих манифестација људске активности и духа, пре свега у другим уметностима, као и у области људске психе, организације и структурираности друштва, религиозне проблематике, филозофских мисли и сл.

Овакво тумачење значења, „откривање“ или „разоткривање“ (lumen naturalus), како га је назвао Де Вејленc, ${ }^{27}$ расправљајући о променама нивоа смисла и форме, производ је пре свега субјективног става, током акције осмишљавања и манипулисања. Свесни да се „смисао појављује са човеком“, наша се феноменолошка позиција пружа у правцу сагледавања новог положаја и значаја музичких инструмената, као коришћених „предмета“ у књижевном опусу. Нови смисаони односи који се ослањају на каузалне везе са особинама њихових реалних представника, предмета који фигуришу у стварном животу, у том случају оправдавају библиографско обухватање, чак и тематски врло удаљених литерараних творевина. Наравно, опет истичемо чињеницу да приликом наведених тумачења, особа која чита грађу може подлећи сугестијама вишеслојног текстуалног значења, само ако у властитом искуству располаже одређеним - реалним сазнањима. ${ }^{28}$ Ингарден јасно дефинише да је свако књижевно и музичко

27 La philosophie et les experiences naturelles / Alphonse de Waehlens. - La Haze, 1961. - стр. 86-106.

28 Оно што се може додати је да је глобализација и по питању третмана материје везане за музичке инструменте, а тиме и рефлексија које произлазе из сазнања о њима, у великом делу људске популације хомогенизовала слична становиштае спознаја и тумачења. Амерички социјални антрополог Едвард Хол запажа да „не само што свака материјална ствар има свој назив, већ се, исто тако, језиком и материјалима често служимо на готово исти начин“. Ово подупире становиште: да било где и било када, изводити онако илустровану Серенаgу уз іитиару вољеној особи, и о таквој радњи писати или је ликовно илустровати, недвосмислено указује на чин који подразумева унапред јасно одређен квалитет људских емоција. Детаљније модалитете анализирања културе погледати у: Неми језик / Едвард Хол. - Београд : БИГЗ, 1976. - 197 стр. 
дело „доступно само у оквиру развијеног процеса естетског схватања“, и да су многи елементи уметничког књижевног дела, као што су „представе приказаних предмета, метафизички квалитет и сл, захваћени одређеним потенцијалитетом бића [ ... $]^{\text {“. }}{ }^{29}$ Финково подкрепљивање, ${ }^{30}$ да је могућност посматрања постојећег у окружењу условљена персоналном сазнајном моћи, елиминише евентуално све остале аспекте таквог сагледавања и тумачења појаве музичких феномена у књижевним делима, дајући читавом проблему трансценденталну разумљивост:

Присетимо се маштовитог описа бачке равнице у лирској прози Вељка Петровића (1884-1967), у којем аутор излаже своје асоцијативно опажање: „А застанеш ли крај насипа са шинама, слушаш сасвим разговетно испрекидно тамбурање зрикаваца и лепет лептирова [...]“.31

У складу са одређеним смеровима посматрања књижевног дела, од којих се један, према Велеку, ${ }^{32}$ протеже до појава изван њих, а други указује на појаву у самом књижевном делу, наша музичка феноменологија нпр. музичких инструмената, тежи да открије њихову амбивалентност (вишеслојност) значења у литератури. Сви помени инструмената, као и стручни - музички термини, који се јављају с њима у вези, постају предмет наше аперцепције, а затим и интердисциплинарне анализе, након које следи филозофска интерпретација и абстракција. Феноменолошки резултати требају пак почивати на дескрипцијама и анализама које потичу од музичких инструмената, као предмета у нашој свести и личног искуства (знања) којим

29 Untersuchungen zur Ontologie der Kunst. Musikwerk, Bild, Architektur, Film / Roman Ingarden. - Tubingen : Max Niemezer Verlag, 1962. -стр. 206-253.

30 Детаљније у: Sein-Wahrheit-Welt / Eugen Fink. - Den Haag, 1958. - стр. 79-91.

31 Похвала равници / Вељко Петровић. - У: Теорија књижевности: Читанка / Драгиша Живковић. - Београд : Научна књига, 1972. - стр. 21. 32 Theory of Literature / R. Wellek, A. Warren. - SAD : New Tork, 1942. 
располажемо. Наглашавамо да се феноменолошке редукције као методолошки поступци, не могу примењивати! По овом питању разилазимо се са становиштем феноменолошке редукције примењене у науци о књижевносоти; њен тамошњи циљ је искључивање свих природних ставова и избацивање из поља посматрања свега што није непосредно садржано у самом делу (све пратеће информације, као што су информације о писцу, епохи, месту и социјалној средини у којој је дело настало и сл.). Без обзира на субјективну спекулативност промишљања, у нашем случају музички инструменти посматрани као књижевни објекти, ни једног тренутка не смеју изгубити хабитус реалности. Њихови најмањи детаљи и трагови, у делима у којима их налазимо, морају сачувати корелацију са стварношћу. Такви сегменти, с логичним упориштем, оправдавају херменеутику тумачења и уобличавања свеукупне целовитости бивства ових музичких изражајних средства, из наизглед чак и сасвим минорних делова и појединости. У обрнутом смеру, структуралност у проучавању ових елемената, чија књижевна употреба скоро да досеже до синтематографије, тада суштински оправдава овакав аналитички приступ.

Имајући у виду, пре свега у области музикологије, неретко суочавање са диспропорцијом релевантне грађе - стручних музикалија, а често и оскудицом оригиналних музичких инструмената појединих епоха, једна од кључних карика, која на адекватан начин повезује и компензује оба недостатка, је управо наведено аналитичко разматрање прикупљених извода, музиком усмереног претраживања уметничке књижевности. Ипак, треба рећи да класична феноменологија, као и феноменолошки приступ књижевном делу, служе понајпре као инспирација проналажењу методолошких поступака при оваквом начном истраживању. Процес којим се дошао до одређених сазнања и када се не би могао сматрати општим модалитетом музичко-књижевног истраживања, извесно је нови код за 
музичку феноменологију у књижевности. Сматрамо да као такав, јасно указује на могуће поступке при свакој даљној идентификацији релевантне библиографске грађе у овој области.

prof. Uroš Dojčinović, PhD

\section{INTRODUCTION TO THE ANALYTICAL ACCESS TO ARTISTIC LITERACY FROM THE MUSIC APPROACH}

\section{Summary}

An interdisciplinary study of literature and music implies a comprehensive approach to the two extremely complementary humanistic areas. Their constant interweaving, in which music and all its aspects are constantly engulfed in philology, produce a new and complex relationship, which can be defined as a musical phenomenology in literature. This work is dedicated to the phenomenological research of all the music present in literature, through concrete examples. In search of literary works, referring to different musical aspects, primarily those related to certain musical instruments in the Serbian territory, the author of this text came to a series of new facts, which are very important for this topic through his practical research. The analysis of extensive artistic literary production was first confirmed by a negligible number of domestic works, in which there were no traces of music issues, while the majority showed a whole range of different connections with musical art in the broadest sense.

Key words: literature, music, analytical approach, musical phenomenology in literature. 